\title{
Study of Shunt Type SFCL Equipped with Electromagnetic Repulsion Switch for Large Capacity
}

\author{
Mikihiko Endo Student Member (Tokyo Denki Univercity,06gme03@ed.cck.dendai.ac.jp) \\ Tomonori Koyama Student Member (Tokyo Denki Univercity, 07gme10@ms.dendai.ac.jp) \\ Yousuke Takahashi Non-member (Tokyo Denki Univercity, 04ke058@ed.cck.dendai.ac.jp) \\ Katsuyuki Kaiho Member (Tokyo Denki Univercity, k-kaiho@aist.go.jp) \\ Satoru Yanabu Member (Tokyo Denki Univercity, yanabu@e.dendai.ac.jp)
}

Keywords: SFCL, electromagnetic repulsion switch, second generation HTS wire

Using a high temperature superconductor, we constructed and tested a model Superconducting Fault Current Limiter (SFCL). SFCL has a vacuum interrupter (VI) with electromagnetic repulsion mechanism. In the proposed SFCL, the current of a superconductor is interrupted with in a half cycle by driving VI with electromagnetic repulsion force. Thus, the load of the superconductor decrease by using this mechanism. And the size of the superconductor will be decreased. Using our SFCL leads to reducing the entire cost of the SFCL.

We set out to construct high voltage class SFCL. We produced the electromagnetic repulsion switch equipped with a $24 \mathrm{kV}$ vacuum interrupter (VI). There are problems that opening speed becomes late. Because the larger vacuum interrupter needs the heavier weight of its contact. For this reason, the current which flows in a superconductor may be unable to be interrupted within a half cycle of current. In order to verify this problem, the current limiting test was conduced.

We carried out a current limiting test using second generation (2G) HTS wire. Figure 2 shows the experimental results. The circuit current is limited from $6 \mathrm{kA}$ to $1 \mathrm{kA}$. Using the larger vacuum interrupter, we succeed in interrupting the current of superconductor within a half cycle.

In a further development we substituted a conventional high speed vacuum circuit breaker (HSVCB) for the electromagnetic repulsion switch as a new method of realizing our concept. In the result, the current of superconductor is interrupted within a half cycle not only electromagnetic repulsion switch, but also HSVCB. This
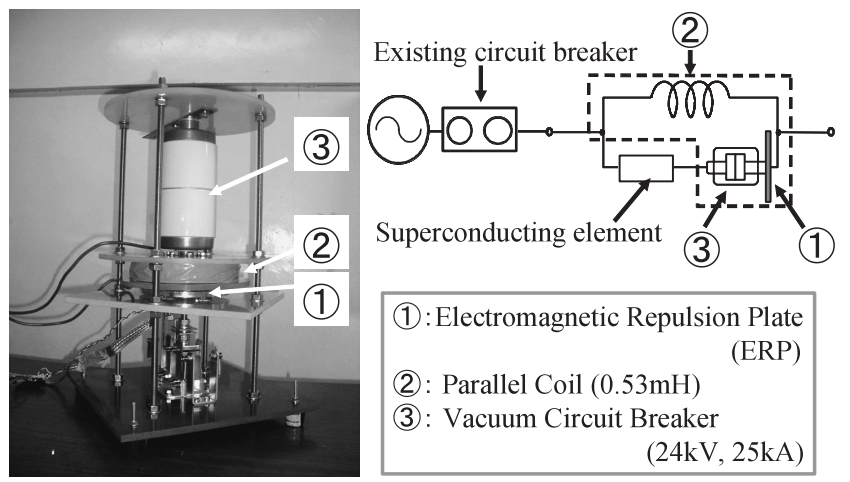

(1):Electromagnetic Repulsion Plate

(2): Parallel Coil $(0.53 \mathrm{mH})$

(3): Vacuum Circuit Breaker $(24 \mathrm{kV}, 25 \mathrm{kA})$

Fig. 1. Photograph and schematic diagram of the fault current limiter success results in one of the new method which actualize our concept of SFCL.

We simulated the method for selecting the electromagnetic repulsion switch adapted to the order of the power system for our proposed SFCL. The result in Fig. 3 indicates that for $63 \mathrm{kA}$ flowing in the parallel coil, sufficient energy to open a gap of $145 \mathrm{kV}$ class VI can be obtained. We also calculated the current flowing for a fault current of $16 \sqrt{2} \mathrm{kA}_{\text {peak }}$ as an example of a small-scale fault. In this case, the current of $14.7 \mathrm{kA}$ flows in the parallel coil. As a result, sufficient energy to open $60 \mathrm{~mm}$ gap in a $145 \mathrm{kV}$ class VI can be obtained. The results indicate that an electromagnetic repulsion switch may be used in electric power systems.

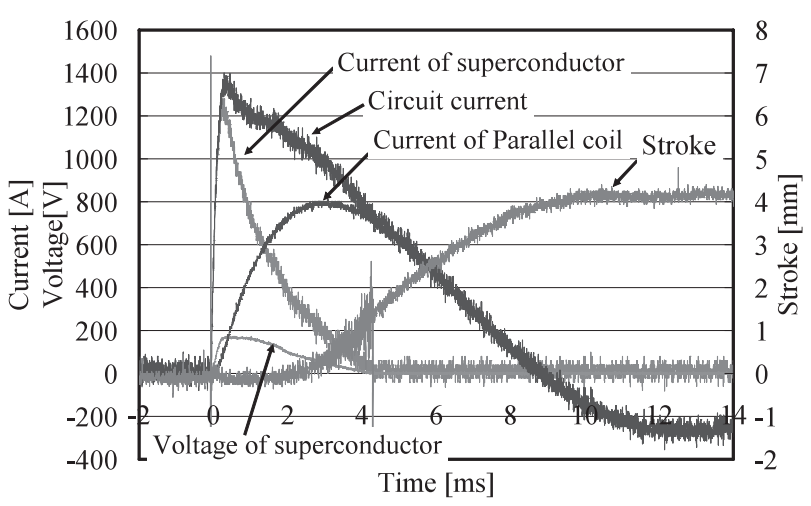

Fig. 2. Experimental result

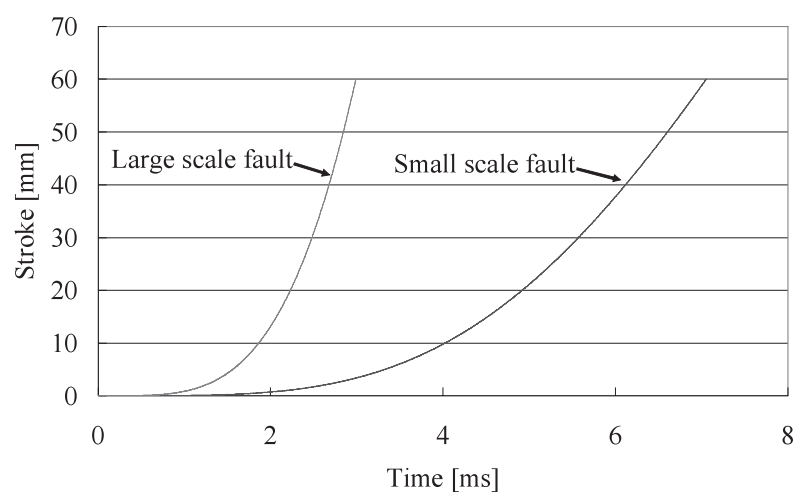

Fig. 3. Drive simulation for $63 \mathrm{kA}$ flowing in the parallel coil 


\title{
電磁反発スイッチを搭載した分流型超電導限流器の 大容量化の検討
}

$\begin{array}{ccccc}\text { 学生員 } & \text { 遠藤 } & \text { 幹彦* } & \text { 学生員 小山 } & \text { 小智徳* } \\ \text { 非会員 } & \text { 高橋 } & \text { 陽介* } & \text { 正員 海保 } & \text { 勝之 } \\ \text { 正 }\end{array}$

\section{Study of Shunt Type SFCL Equipped with Electromagnetic Repulsion Switch for Large Capacity}

Mikihiko Endo*, Student Member, Tomonori Koyama*, Student Member, Yousuke Takahashi*, Non-member, Katsuyuki Kaiho*, Member, Satoru Yanabu*, Member

\begin{abstract}
Using a high temperature superconductor, we constructed and tested a model Superconducting Fault Current Limiter (SFCL). SFCL we proposed has a vacuum interrupter with electromagnetic repulsion mechanism. We set out to construct high voltage class SFCL. We produced the electromagnetic repulsion switch equipped with a $24 \mathrm{kV}$ vacuum interrupter (VI). There are problems that opening speed becomes late, because the larger vacuum interrupter needs the heavier weight of its contact. For this reason, the current which flows in a superconductor may be unable to be interrupted within a half cycles of current. In order to solve this problem, it is necessary to change the design of the coil connected in parallel and to strengthen the electromagnetic repulsion force at the time of opening the vacuum interrupter. Then, the design of the coil was changed, and in order to examine whether the problem is solvable, the current limiting test was conduced. We carried out a current limiting test using second generation (2G) HTS wire. The element which is used in this experiment has stainless steel stabilizer both side of the wire. As a result, we succeed in interrupting the current of a superconductor within a half cycle.
\end{abstract}

キーワード：限流器, 電磁反発スイッチ, 次世代高温超電導線材

Keywords: SFCL, electromagnetic repulsion switch, second generation HTS wire

\section{1. はじめに}

限流器は，巨大な電力系統において短絡や地絡といった 故障が生じた際に, 系統に流れる過大な電流を瞬時に抑制す る装置である。近年の酸化物高温超電導素子の発見によっ て, 超電導技術を用いた限流器の開発が様々な研究機関で 行われており，これまでにも様々な方式の超電導限流器が 試作・検討されている(1) (3)。将来, 限流器が系統に適用さ れることになれば, 系統保護遮断器の格上げや系統分離・ 再編成といった対策をとるためのコストが大幅に軽減され， 信頼性向上および系統安定度確保などの有用な効果を期待 することができる。種々の方式の超電導限流器の中でも, 我々は簡易構成で原理が容易な抵抗発生型超電導限流器の 試作および実験を行ってきた。

\footnotetext{
東京電機大学

₹ 101-8457 東京都千代田区神田錦町 2-2

Tokyo Denki Univercity

2-2, Nishikityou-Kanda, Chiyoda-ku, Tokyo 101-8457
}

最近の限流器の方式として, 超電導素子の負担を軽減す るために超電導素子の通電時間を短くする方式が用いられ はじめている。その方式の例として, 超電導素子に直列に 転流用スイッチを接続し, それらと並列に限流用バイパス インピーダンスを接続するする方法が検討, 提案されてい る $(\text { Siemens 他 })^{(4)}$ 。我々が検討している方式もその方式の 一つである(5)。この方式で系統故障時における超電導素子 への過大電流時間を短縮するためには, 短時間で開極する 特殊なスイッチが必要となる。そこで我々は, 系統故障時 の過大電流が超電導素子に流れ, 超電導素子がクエンチす ることで過大電流をバイパスインピーダンスに分流した時 に発生したエネルギーを利用して真空バルブの可動電極部 を電磁反発力で駆動する方式に着目した。以降，この方式 のスイッチを電磁反発スイッチと呼ぶことにする。この電 磁反発スイッチにより超電導素子に流れる電流を高速で遮 断し, 超電導素子の消費エネルギーの低減を可能とした簡 易構成の分流型超電導限流器の開発を行っている。

本論文では，電磁反発スイッチを使用することにより超 
電導素子に流れる電流を最小限にし, 超電導素子にかかる 負担を大幅に軽減することのできる限流器の大容量化につ いて検討する。

\section{2. 提案する限流器}

従来の抵抗発生型超電導限流器は, 超電導素子それ自身 で電流を限流するため系統で故障が発生し, 故障電流が流 れてから系統に設置された遮断器で故障電流が遮断される までの間, 超電導素子に故障電流が流れるため, 超電導素 子クエンチ時のジュール発熱による超電導素子の溶断や破 壊の問題がある。さらに高電圧遮断器には, 高速再閉路の 責務も課せられており, 故障電流遮断後 0.3 秒で回路を再 び投入しなければならない (6)。この遮断器の再閉路責務に 対応するために, 超電導素子は 0.3 秒以内に超電導状態に 戻っていることが必要とされ, 超電導復帰時間の問題は, 超電導限流器の開発において重要な課題となっている。し たがって，系統故障時に超電導素子での消費エネルギーを 最小限に抑えることが望ましい。そこで我々は，超電導素 子の消費エネルギーの軽減を目的とした，簡易構成の抵抗 型（分流型）超電導限流器を検討している (Fig. 1)。この 限流器は, 超電導素子と市販の真空バルブが直列に接続さ れ，それらと並列に限流および電磁反発スイッチ駆動用の コイルの構成となっている。Fig. 1 中点線で囲われた部分 が，真空バルブ，電磁反発板並びに並列コイルから構成さ れる電磁反発スイッチである。この電磁反発スイッチは, 実際の電力系統を模擬した構成となっている。そのモデル は, 定格電圧 $66 \mathrm{kV}$, 定格電流 $1 \mathrm{kA}$, 系統故障時の故障電 流 $60 \mathrm{kA}$ を $66 \mathrm{kV}$ 系統に設置されている遮断器の定格遮断 電流 $31.5 \mathrm{kA}$ に限流することを目的としている。本限流器 では，並列コイルが限流インピーダンスとして働くため, このモデルの場合必要となる並列コイルのインピーダンス は $0.58 \Omega(1.84 \mathrm{mH})$ となる。したがって，この並列コイ ルに限流電流 $31.5 \mathrm{kA}$ が流れると，並列コイルの両端には 約 $18 \mathrm{kV}$ 印加されることになる。したがって，電磁反発ス イッチに搭載する真空バルブは, 定格電圧 $24 \mathrm{kV}$, 定格電流 $1200 \mathrm{~A}$ ，定格遮断電流 $25 \mathrm{kA}$ の真空バルブを使用した。並 列コイルは，実験設備の関係上このモデルを模擬すること が困難であるため, 既存の実験設備で動作させることを考慮 し, 巻き数が 61 ターン，インダクタンスが $0.53 \mathrm{mH}$ となっ ている。また, 電磁反発板は, 厚み $10 \mathrm{~mm}$, 直径 $168 \mathrm{~mm}$ の アルミニウム製の円形板となっている。また，実験に使用 する超電導素子も $66 \mathrm{kV}$ に適用するのに必要となる超電導 素子に比べて少ない量の超電導素子を用いて実験を行った。

この限流器の動作について説明する。まず，定常状態で は超電導素子は超電導状態であるため, 低損失で送電する ことができる。一方，系統故障時に，超電導素子に過大な 故障電流が流れると, 超電導素子は常電導転移し抵抗を発 生し，過大な電流は並列に接続されているコイルに分流す る。並列コイルに電流が流れたことにより磁界が発生し， この磁界により真空バルブの可動接触子に固定された電磁
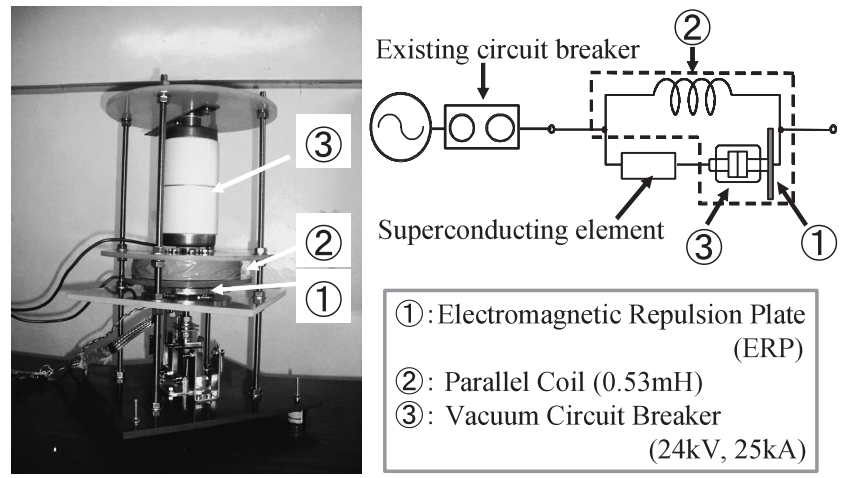

(1): Electromagnetic Repulsion Plate

(2): Parallel Coil $(0.53 \mathrm{mH})$

(3): Vacuum Circuit Breaker

$(24 \mathrm{kV}, 25 \mathrm{kA})$

Fig. 1. Photograph and schematic diagram of the fault current limiter.

反発板内部に並列コイルとは逆向きの渦電流が誘起される ため, 電磁反発板は反発し, 真空バルブの可動接触子を駆 動させる。この一連の動作で, 超電導素子に流れる電流を 理想的には交流半波で遮断することができる。この高速動 作が可能な電磁反発スイッチの実現は, 超電導素子クエン チ時の発生抵抗を利用して, 故障電流を並列コイルに分流 し, 並列コイルに発生した磁界で電磁反発スイッチ駆動す るため, 故障電流を検出する装置も必要なく, 構造が簡単 になるというメリットがある。さらに, 電磁反発スイッチ に使用する電流遮断部には，その耐圧さえ満たせば市販の 遮断器（真空バルブ）を使用することができ, 並列コイル は，巻き数を変更することで系統から要求される限流イン ピーダンスの変更に対応できるので, 超電導限流器として の設計自由度も高く，コスト面からも実用的であるといえ る。また，この並列コイルは第 7 章で詳しく述べるが，限 流器に印加される電圧を低くする効果も果たしている。こ の電磁反発スイッチによって, 超電導素子に流れる電流を 交流半波で遮断することができるため超電導素子の消費工 ネルギーの低減や超電導復㷌時間の短縮が期待できる。

\section{YBCO 線材の仕椂及び実験回路}

〈3.1 Y YBCO 線材の仕様 我々の検討している限流 器は, 超電導素子がクエンチした時の発生抵抗を利用して 並列コイルに電流を分流し，故障電流を抑制する。このた め, 使用する超電導素子は, クエンチ時の発生抵抗が大き いほうが望ましい。そこで，これまでクエンチ時の発生抵 抗が大きい YBCO 薄膜を用いて研究を行ってきた。一般的 に YBCO 薄膜は, クエンチ時の局所的な温度上昇から保護 するために並列抵抗を接続したり金や銀の金属を皮膜した りする。しかし，これらは設置面積の増大や使用する超電 導素子量の増加を招き，コストが増大してしまう。さらに， 一枚で許容できる電流電圧に限界があるため, 高電圧大電 流化する為には複数枚直並列接続しなければならない。こ の際，全ての超電導素子の電流電圧を均等に分流分圧する ように配慮しなければならず，装置が複雑化する恐れもあ る。また，YBCO 薄膜は，劣化の心配もあり，信頼性の面 でも問題がある。一方, RE (REBa2Cu3Oy, RE: 希土類元 


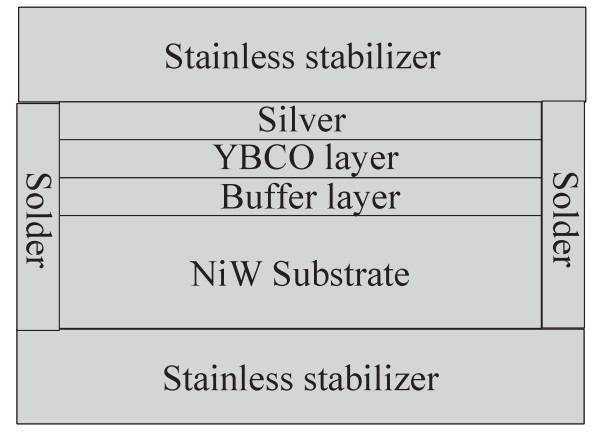

Fig. 2. Cross section diagram.

Table 1. Specifications of $344 \mathrm{~S}$ wire.

\begin{tabular}{c|c}
\hline \hline Manufacturer & AMSC $^{\circledR}$ \\
\hline $\begin{array}{c}\text { Critical current } \\
\text { (@ } 77 \mathrm{~K}, \text { self-field) }\end{array}$ & $91 \mathrm{~A}$ \\
\hline Dimension & $\begin{array}{c}\text { Width; } 4.4 \mathrm{~mm} \\
\text { Thickness: } 0.15 \mathrm{~mm}\end{array}$ \\
\hline Stabilizer material & Stainless steel \\
\hline Thickness of stabilizer & $25 \mu \mathrm{m}$ (Both side of wire) \\
\hline $\begin{array}{c}\text { Resistance per length } \\
\text { @ room temperature) }\end{array}$ & $0.33 \Omega / \mathrm{m}$ \\
\hline \hline
\end{tabular}

素) 系超電導素子は, 磁界中での臨界電流密度の特性に優 れており，マグネットやケーブル等の電力応用機器への応 用が期待されている(7)。その一つとして限流器への適用が 考えられている。YBCO 線材は，YBCO 薄膜に比べて長尺 化が容易であり高電圧大電流化の際に，一本の線で対応で きるため，接続点を減らすことができ装置の単純化が見込 むことができる。さらに，機械的強度もあり，劣化の心配 もほとんどないため再現性のある特性を期待することがで き，信頼性の面でも有用であるといえる。以上のような理 由から本実験では超電導素子としてアメリカンスーパーコ ンダクター社の $344 \mathrm{~S}$ 線材を用いた。この線材の断面図と 仕様をそれぞれ Fig. 2，Table 1 に示す。YBCO 線材は，一 般的に安定化金属として銅や銀を積層するが，この線材は， 両端にステンレススチールが積層されている。したがって, 銅や銀に比べてクエンチ時に高い発生抵抗を期待できるた め, 我々の提案する限流器に適していると考え採用した。

実験に際しては，第 2 章で想定したようなモデルに適用 できるような線材考えると複数の線材の直列並列接続が必 要となる。我々がこれまで行った実験からこの線材で直並 列接続は問題なく動作することを確認している。しかし， 実際に $66 \mathrm{kV}$ 系統で用いるだけの線材を準備することが困 難であったため, 長さ $1 \mathrm{~m}$ の線材 1 本を用いて実験を行っ た。この線材を円筒形状の筒に巻きつけることにより供試 コイルを作製し試験を行った。供試コイルの外観と仕様を それぞれ Fig. 3, Table 2 に示す。

〈3.2〉 実験回路 実験に使用した回路を Fig. 4 に示

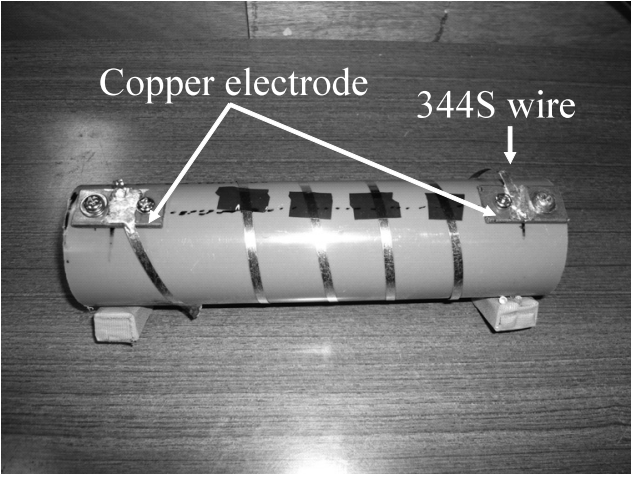

Fig. 3. Appearance diagram of testing coil.

Table 2. Specifications of testing coil.

\begin{tabular}{c|c}
\hline \hline Material & $344 \mathrm{~S}$ wire \\
\hline Length & $18 \mathrm{~mm}$ \\
\hline Diameter & $60 \mathrm{~mm}$ \\
\hline Number of turn & 5 turn \\
\hline Length of wire & $1 \mathrm{~m}$ \\
\hline Inductance & $1.7 \mu \mathrm{F}$ \\
\hline \hline
\end{tabular}

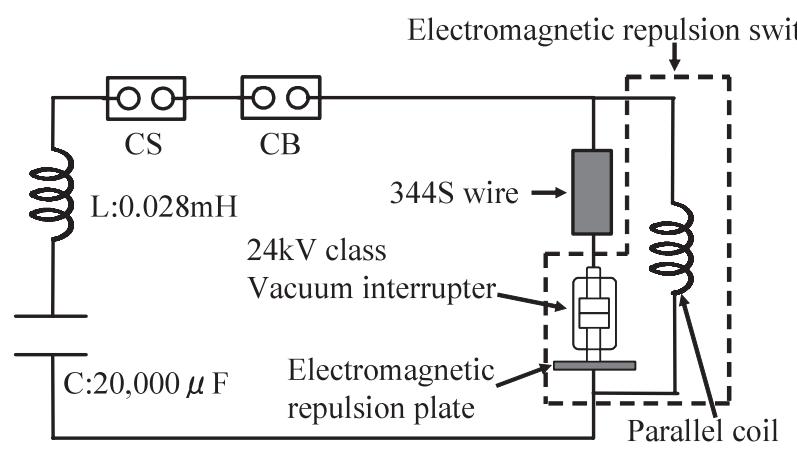

$(0.53 \mathrm{mH})$

Fig. 4. Experimental circuit.

す。電源には LC 共振回路電源を用い, 限流器を接続して 限流実験を行った。実験では，まずコンデンサ $(20,000 \mu \mathrm{F})$ に充電し, 投入器 $(\mathrm{CS})$ を動作させることにより, 系統故 障電流を模擬した過電流を通電した。故障電流の大きさは コンデンサ $(20,000 \mu \mathrm{F})$ の充電電圧により調整した。測定 は, 回路電流, 並列コイルの電流, 電磁反発スイッチのス トローク，超電導素子の電圧を測定した。

本実験回路では，電源に LC 共振回路を用いているため, 超電導素子クエンチ後は, 回路に電磁反発スイッチの並列コ イルが入ってくる。このため, 回路周波数が変化してしまい $50 \mathrm{~Hz}$ から外れてしまう。そこで本実験では, 実系統 $(50 \mathrm{~Hz})$ により近い状態を模擬するために超電導素子がクエンチし, 電磁反発スイッチによって超電導素子が回路から切り離さ れた後, 回路がコンデンサ $(20.000 \mu \mathrm{F}), \mathrm{L}(0.028 \mathrm{mH})$, 並 


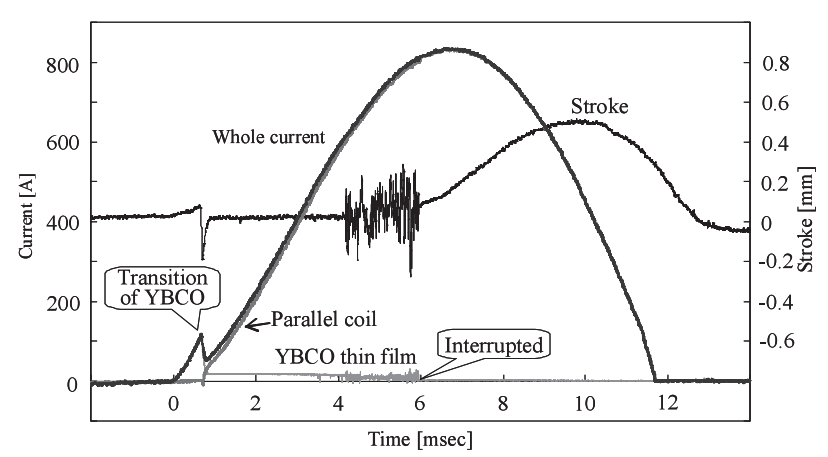

Fig. 5. Sample of the experimental waveform.

列コイル $(0.53 \mathrm{mH})$ の直列回路となることを考慮し，この 時の周波数が約 $50 \mathrm{~Hz}$ となるように回路を構成した。

\section{4. 電磁反発スイッチを用いた限流実験}

我々は，これまで試作限流器を製作しその動作実験を行っ ている。動作試験の一例を Fig. 5 に示す。この実験では交流 $50 \mathrm{~Hz}, 50 \mathrm{~V}$ を電源として用い, 交流半波電流を試作超電導 限流器に通電した。超電導素子は, 幅 $20 \mathrm{~mm}$, 長さ $10 \mathrm{~mm}$, 厚み $25 \mu \mathrm{m}$ の YBCO 薄膜を $6.6 \mathrm{kV}$ の真空バルブを搭載し た電磁反発スイッチに接続して実験を行った。また，電磁 反発スイッチの並列コイルのインダクタンスは $0.15 \mathrm{mH}$ と なっている。Fig. 5 において, 超電導素子のクエンチと同 時に並列コイルに殆どの電流が分流し, 電磁反発板が駆動 し超電導素子の電流が遮断されていることが分る。電磁反 発スイッチのストロークが開極してから $0 \mathrm{~mm}$ に戻ってい るがこれは，並列コイルの電流が減少していくにつれて電 磁反発力が弱まり真空バルブの自閉力の方が強くなり接点 が閉極状態に戻ったためと考えられる。

我々の限流器をさらに大容量化するためには搭載する真 空バルブを大容量化する必要がある。これに伴い，電磁反 発スイッチも大型化が必要となってくる。しかし, 電磁反 発スイッチは，機械的な駆動部を有しているため大型化す ると動作スピードが遅くなることが懸念される。そのため, 超電導素子に流れる電流を 0.5 サイクル以内に遮断できな い恐れが出てくる。そこでこの問題を解決できるか否かを 検証するために新たに第 2 章で述べたこれまでよりも大容 量の $24 \mathrm{kV}$ の真空バルブを搭載した試作器を製作し，その 試作器に超電導素子を接続し, 限流実験を行った。実験結 果をFig. 6 に示す。測定波形を見てみると，通電開始から 約 $3 \mathrm{~ms}$ 後に並列コイルの電流が $700 \mathrm{~A}$ 付近になったとこ ろで真空バルブが駆動し始め, 通電から約 $4 \mathrm{~ms}$ 後に超電導 部の電流を遮断していることがわかる。本実験で使用した 実験回路では，限流器を接続しなかった場合，回路には約 $6 \mathrm{kA}$ 程度の電流が流れる。すなわち, 限流器を接続するこ とにより回路電流は $1 \mathrm{kA}$ まで抑制することにできた。スト ロークが $4.0 \mathrm{~mm}$ のところで開極状態を保持しているがこ れは, 試作器には真空バルブが開極後その状態を保持でき るように開極保持装置が取り付けられているためである。

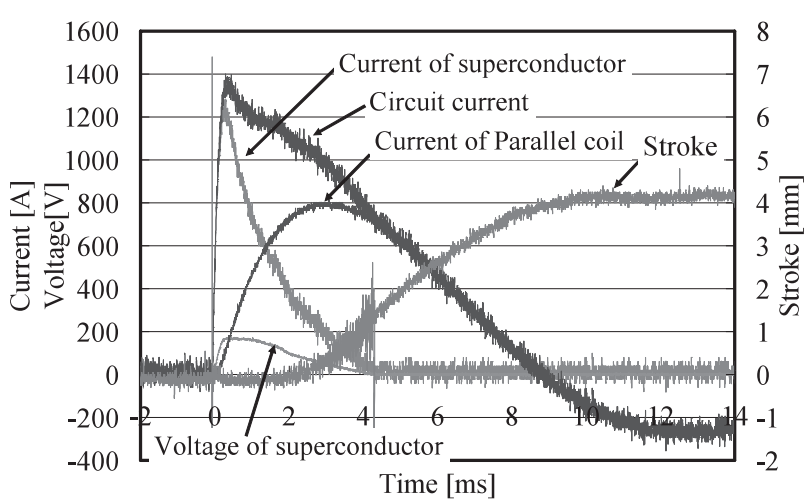

Fig. 6. Experimental result.

本実験では, $66 \mathrm{kV}$ 系統への適用を目的とした電磁反発ス イッチを試作し, その限流実験を行った。実験設備の関係 から第 2 章で想定したモデルを模擬することはできなかっ た。しかし, 本限流器において, 超電導素子は, 必要とな る電流電圧を満たし並列コイルに電流を分流できるだけの 抵抗值があれば良い。したがって，本実験では，1 $\mathrm{m}$ の線 材一本で実験を行っているが $66 \mathrm{kV}$ に必要となる線材さえ

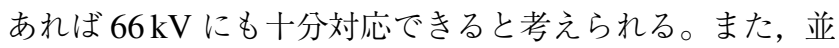
列コイルも想定したモデルよりも小さい值を用いているが, 本実験でも示したとおり, 電磁反発スイッチの設計を適切 に行えば十分動作させることができると考えられる。した がって, 本限流器は $66 \mathrm{kV}$ 系統へ適用可能であると考えら れる。

\section{5. 高速遮断器を用いた限流実験}

我々の提案する限流器が超電導素子の負担を軽減する効 果的な方式の一つであることは先に述べた。ここでは, 我々 のコンセプトを実現する方式の一つとして電磁反発スイッ チに換え従来型の高速遮断器（Fig. 7, Table 3) を接続し, 超電導素子に流れる電流を 0.5 サイクル以内に遮断できる かどうか遮断試験を行った。実験は, Fig. 4 中の真空バル ブと電磁反発板の部分に高速遮断器を接続して行い, その 他の回路は電磁反発スイッチを用いた限流実験と同様であ る。高速遮断器動作には, 超電導素子がクエンチ時に発生

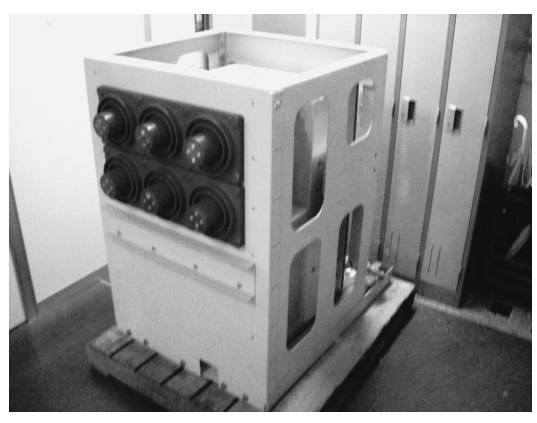

High Speed Vacuum Circuit Breaker (HSVCB)

Fig. 7. Appearance diagram of HSVCB. 
Table 3. Specifications of HSVCB.

\begin{tabular}{c|c}
\hline \hline Rated Voltage & $7.2 \mathrm{kV}$ \\
\hline Rated current & $600 \mathrm{~A}$ \\
\hline Rated interrupting current & $12.5 \mathrm{kA}$ \\
\hline \hline
\end{tabular}

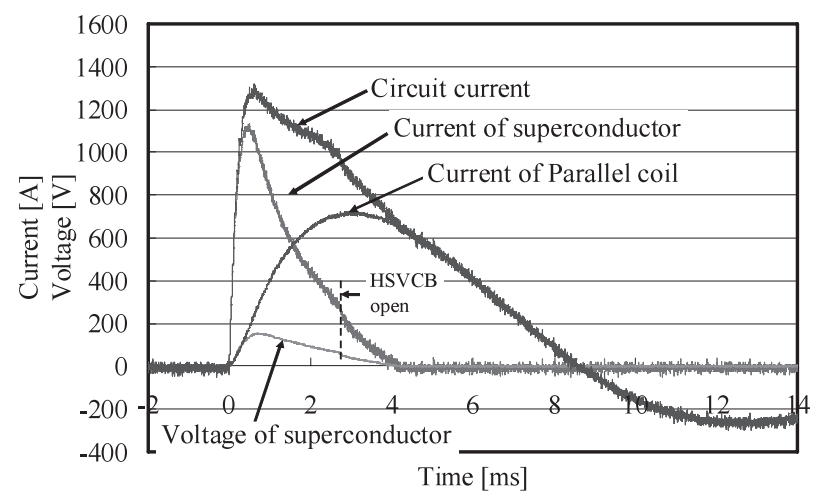

Fig. 8. Experimental result.

する電圧を検出し，遮断器に開極指令信号が入るようにし た。実験結果を Fig. 8 に示す。Fig. 8 を見てみると電流通 電後 $3 \mathrm{~ms}$ 後に超電導素子の電流電圧がわずかに歪んでい る事から高速遮断器が開極し始めていると推測できる。そ の後, 通電から約 $4 \mathrm{~ms}$ 後, 電流零点をむかえ遮断している ことがわかる。このことにより, 市販の高速遮断器でも超 電導素子に流机る電流を 0.5 サイクルで遮断することがで き，我々のコンセプトを実現する方法の一つを見出した。

\section{6. 限流器の電力系統への適応検討}

$\langle 6 \cdot 1\rangle 500 \mathrm{kV}$ 系統適用モデルこの項では，我々が 検討する限流器の概念設計および適用する系統の容量に応 じた遮断部と超電導部分の選定の一例を述べる。例では, 線間電圧 $500 \mathrm{kV}$, 定格電流 $8 \mathrm{kA}$ の系統で, 最大の短絡電 流を $100 \mathrm{kA}$ とし, この電流を $63 \mathrm{kA}$ 程度に抑制する超電導 限流器を考える。超電導限流器の臨界電流值は, 变圧器投 入時の励磁突入電流等の故障時以外に超電導素子がクエン チしないようにすることを考慮し，ここでは仮に定格電流 （8kA）の 2 倍の $16 \mathrm{kA}$ と設定した。ここで，電圧および 電流は，すべて実効值として考える。この条件から，短絡 インピーダンス $\left(\mathrm{X}_{\mathrm{S}}\right)$ と限流器に必要となる限流インピー ダンス $\left(\mathrm{X}_{\mathrm{L}}\right)$ を計算すると Fig.9のようになる。

以上の条件より, 電磁反発スイッチ㧍よび超電導部分の 選定考えてみる。

$\langle\mathbf{6} \cdot \mathbf{2}\rangle$ 電磁反発スイッチの適用検討上記のモデル 系統に適用する電磁反発スイッチを，駆動シミュレーショ ンを作成し検討してみた ${ }^{(8)}$ 。想定するコイルは, 最大短絡時 に, 並列コイルに拉よそ $63 \mathrm{kA}$ の電流が $550 \mathrm{kV} / 63 \mathrm{kA}$ の遮 断器の遮断時間の 3 5 サイクル流れると考えると㧍扮よそ 直径 $20 \mathrm{~mm}$ の電線が必要となり, この電線でコイルを巻く ものとし, 計算には内半径 $600 \mathrm{~mm}$, 外半径 $800 \mathrm{~mm}$, 高さ

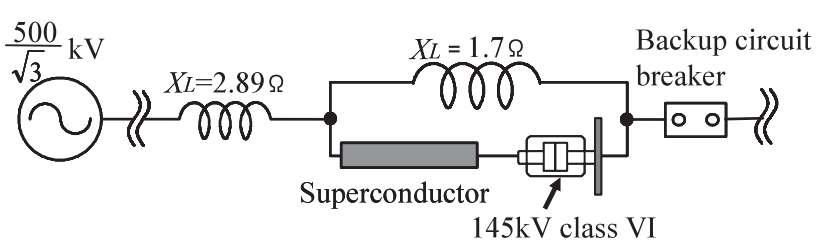

Fig. 9. Calculation model of $500 \mathrm{kV}$ transmission line.

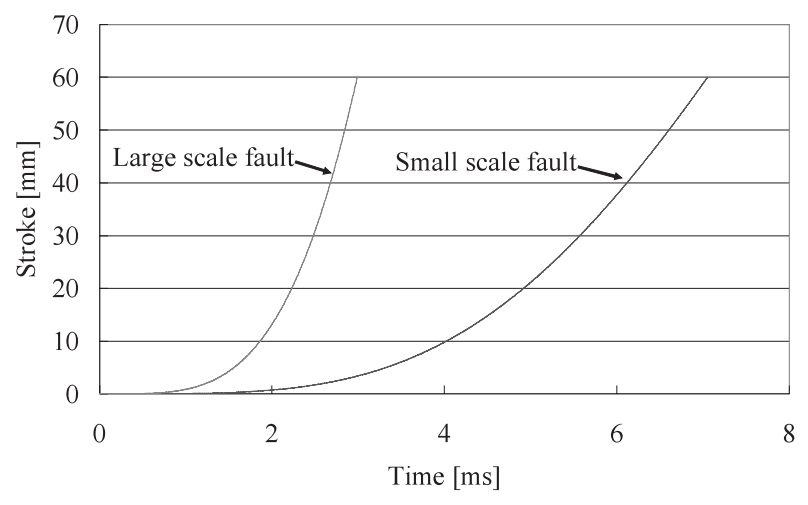

Fig. 10. Drive simulation for $63 \mathrm{kA}$ flowing in the parallel coil.

$1000 \mathrm{~mm}$ の円盤卷きコイルとした。また，電磁反発板は， 半径 $800 \mathrm{~mm}$, 厚み $20 \mathrm{~mm}$ とし電磁反発板はコイルの一端 に近接して設置するものとした。本構成において並列コイ ルが限流インピーダンスとして働くことから, $100 \mathrm{kA}$ の故 障時には抑制電流 $63 \mathrm{kA}$ が並列コイルに流れる。したがっ て, その両端には $107 \mathrm{kV}$ 印加されるためこの值以上の耐圧 を持つ真空遮断器を適用する必要がある。ここでは $145 \mathrm{kV}$ 級の真空バルブの適用をするものと仮定した(9)。ギャップ 長は $60 \mathrm{~mm}$ とした。な扔，本シミュレーションに扔いて $145 \mathrm{kV}$ クラスの真空バルブの自閉力や動作時の摩擦, 電磁 反発スイッチの絶縁設計等詳細な部分については考慮に入 れていない。これらの条件を用いて駆動シミュレーション を行った。その結果を Fig. 10 に示す。結果からも分るとお り, 並列コイルに抑制電流 $63 \mathrm{kA}$ が流れた場合には, $145 \mathrm{kV}$ 級の真空バルブを $60 \mathrm{~mm}$ 開極するのに十分なエネルギーを 得ることができることが予想できる。一方，故障規模には 様々な場合が想定され $100 \mathrm{kA}$ の故障電流が流れるような 大規模故障もあれば, 超電導素子がやっとクエンチするよ うな小規模故障も考元られる。そこで, 小規模故障の一例 として先のモデルで定めた超電導素子の臨界電流値 $16 \mathrm{kA}$ の故障電流が流れた場合を考える。この場合, 並列コイル には $14.7 \mathrm{kA}$ 流れる。その結果も同様に Fig. 10 に示す。こ の場合も $63 \mathrm{kA}$ 流れた場合と同様に $145 \mathrm{kV}$ の真空バルブ を $60 \mathrm{~mm}$ 開極するのに十分な駆動エネルギーを得ることが 予想できることがわかった。

本シミュレーションを用いて, 論文中で述べられている 電磁反発スイッチの駆動特性とシミュレーションを比較し た結果, 誤差が見られた。しかし, その誤差は, シミュレー ション結果よりも実測結果の方が並列コイルに流れる電流 が低い值で動作するものであった。したがって，この節で 
述べられているシミュレーションよりも低い電流值で動作 することが予想できる。

本シミュレーションでは, 絶縁面や真空バルブの自閉力 等詳細な部分に関しては無視しているものの, 我々の提案 する電磁反発スイッチが高電圧系統においても十分適用可 能である見通しを得た。

\section{7. 考察}

本論文において，これまでの電磁反発スイッチよりも大 容量の電磁反発スイッチを試作しそれに超電導素子を接続 した試験において良好な結果を得ることができ，大容量化へ の見通しを得た。さらに，500 kVへの適用シミュレーショ ンでは最大故障規模だけでなく超電導素子がぎりぎりクエ ンチするような比較的小規模の故障においても十分動作す ることが分った。しかし，本シミュレーションでは簡易な モデルでのシミュレーションであるため，より詳細な検討 については行っていない。そこでこの節では，電磁反発ス イッチの電力系統への適用の検討について考察してみる。

まず，この限流器を用いるメリットとして以下のような 点が挙げられる。

（1）超電導素子に流れる電流を理想的には交流半波で 遮断するため, 超電導素子の負担を軽減することができる。 これにより，必要となる超電導素子数の削減，復帰時間の 短縮が期待できる。

（2）電磁反発スイッチの駆動エネルギーに並列コイル に過大電流が流れた時のエネルギーを利用しているため駆 動用外部電源を必要とせず，装置の小型化につながる。

（3）限流器に印加される電圧が，電源のインピーダン スと並列に接続された限流用インピーダンスで分圧される ため, 電源電圧に比べて低くすることができ限流器の小型 化，コスト低減につながる。

(4) 限流器に印加される電圧が電源電圧に比べて低く することができるため, $500 \mathrm{kV}$ 系統に適用する場合でも電 磁反発スイッチに搭載する真空バルブが $145 \mathrm{kV}$ クラスで すむ。

（5）本方式では，超電導素子はトリガとして用いられ 限流は並列のリアクタンスによって行われる。そのため, 超電導復帰中や万が一超電導素子が破壊してしまった場合 でも，並列リアクトルにより系統は故障抑制状態を維持し ていることができる。

（6）本方式では，並列に接続するインピーダンスの值 を調整することで限流電流值の調整ができる。

一方，先に述べたシミュレーションでは，簡易なモデル の電磁反発スイッチを考えその検討を行った。その結果， 我々の検討する電磁反発スイッチの電力系統での適用の見 通しを得た。しかし，実際に系統で適用する場合さらに詳 細な検討について行う必要がある。例えば，以下のような 点が考えられる。

（1）真空バルブの接点は，バットコンタクトであるた め，特に系統短絡事故時などの大電流通電時には接点部に
大きな反発力が働く。このため，閉極時に可動電極をある 一定の荷重で固定電極に押し付ける接圧力が必要となる。

（2）過大電流が並列コイルに流れ強力な電磁反発力が 真空バルブに働き，真空バルブのベローズの損傷を招く恐 れがあるためそれを保護する機構を設ける。

（3）現在の電磁反発スイッチでは，開極後その状態を 保持する機構はあるが，再び投入する機構は備えていない。 遮断器には上記でも述べたとおり高速再閉路責務も課せら れており，電磁反発スイッチもそれに対応する必要がある。 従って, 外部電源無しに 0.3 秒以内に再投入できるような 機構を現在検討中である。

その他にも限流器全体の絶縁設計等今後, 提案する限流 器を電力系統へ適用する場合は上記のような点を検討して いく必要がある。

第 5 章でも述べたように電磁反発スイッチの替わりとし て沉用の高速遮断器を使用する方法も考えられる。しかし, 高速遮断器を用いた場合，その電流遮断部は大地との絶縁 等の理由から遮断部は上方に配置され, 操作機構部は接地 する必要があるため下方部に配置される。このため，上方 にある接点を下方にある操作機構部で動作させることとな り，高速に動作させることが困難となってしまうことが予 想される。もし，実現が可能となったとしても大きなエネ ルギーが必要となり装置の大型化を招きかねない。一方, 我々の検討する方式では, 電磁反発スイッチの開極に系統 故障時の過大電流が並列コイルに流れた時のエネルギーを 使用しているため, その操作機構部を必要としない。した がって，簡単な機構で高速動作させる事が可能であり，高 速遮断器を用いるよりも，我々の提案する電磁反発スイッ チの方が有効な手段であると考えられる。

\section{8. まとめ}

本論文では，これまでよりも大容量の電磁反発スイッチ を試作し，その駆動特性の検討と市販の高速遮断器を用い て遮断試験を行った。さらに, 電磁反発スイッチの電力系 統への適用の検討を行った。その結果，以下のような事が わかった。

（1） $66 \mathrm{kV}$ 系統への適用を想定した試作限流器におい て，超電導部に流れる電流を 0.5 サイクル以内に遮断する ことに成功した。これにより電磁反発スイッチの大容量化 への見通しを得ることができた。

（2）電磁反発スイッチの替わりとして，市販の高速遮 断器を用いた試験においても, 超電導部に流れる電流を 0.5 サイクル以内に遮断することに成功した。これにより, 我々 のコンセプトを実現する方式の一つを見出した。

（3）実系統への適用検討をした結果，最大規模の事故 時から比較的小規模の事故時で電磁反発スイッチが動作す るシミュレーション結果を得ることでき，電磁反発スイッ チの実系統での使用の見当がついた。

今後は，電磁反発スイッチの詳細な検討や超電導素子の 耐久性の向上はもちろんであるが，超電導素子の使用量の 
削減, コストの低減や超電導復帰時間の検討などを行って いく予定である。

(平成 19 年 10 月 11 日受付, 平成 20 年 4 月 9 日再受付)

$$
\text { 文献 }
$$

(1) H. Schmitt, J. Amon, et al: "Fault Current Limiters-Application, Principles and Experience", CIGRE WG A3.16, CIGRE SC A3 \& B3 Joint Colloquium, No.205 (2005)

(2) K. Shimohata, S. Yokoyama, T. Inaguchi, S. Nakamura, and K. Yasuda: "Quench characteristics of fault current limiting element with YBCO thin film", IEEE Trans. Appl. Supercond., Vol.13, No.2, pp.2108-2111 (2003-6)

(3) M. Noe, K.-P. Juengst, S. Elschner, J. Bock, F. Breuer, R. Kreutz, M. Kleimaier, K.-H. Weck, and N. Hayakawa: "High voltage design, requirements and tests of a 10 MVA superconducting fault current limiter", IEEE Trans. Appl. Supercond., Vol.15, No.2, pp.2082-2085 (2005-6)

(4) H.-P. Kraemer, et al: "Test of a 2 MVA medium voltage HTS fault current Limiter module made of YBCO coated conductors", Proc. EUCAS'07 (2007)

(5) T. Hori, et al: "Study of Superconducting Fault Current Limiter Using Vacuum Interrupter Driven by Electromagnetic Repulsion Force for Commutating Switch", IEEE Trans. Appl Supercond, Vol.16, No.4, pp.1999-2004 (2006-12)

（6）「交流遮断器」,JEC-2300-1998, 電気学会電気規格調査会標準規格, p.35, 電気書院 (1998)

（7）塩原 融：「次世代高温超電導線材の特徵と研究開発動」, 電学誌, Vol.126, No.5, pp.268-271 (2006)

(8) T. Takeuchi, K. Koyama, and M. Tsukima: "Electromagnetic analysis coupled with motion for high speed circuit breakers of eddy current repulsion using the tableau approach", IEEJ Trans. PE, Vol.124, No.6, pp.859-865 (2004-6) (in Japanese)

竹内敏恵・小山健一・月間 満:「等価回路モデルによる渦電流反発 式高速遮断器の駆動解析」, 電学論 B, 124, 6, pp.859-865 (2004-6)

(9) H. Okubo: "Technical Trend of Environment-friendly High-Voltage Vacuum Circuit Breaker", IEEJ Trans. PE, Vol.123, No.2, pp.129-132 (2003-2) (in Japanese)

大久保仁：「環境低負荷の真空遮断器（VCB）高電圧化技術動向」, 電 学論 B, 123, 2, pp.129-132 (2003-2)

遠 藤 幹 彦

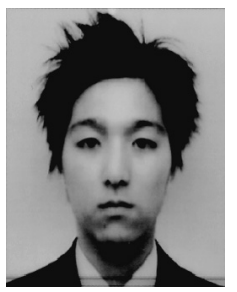

(学生員) 1983 年 2 月 15 日生。 2006 年 3 月東 京電機大学工学部電気工学科卒業。同年 4 月同大 学大学院工学研究科電気工学専攻博士前期課程に 入学。以来, 高温超電導限流器の開発に関する研 究に従事。

小山智 徳

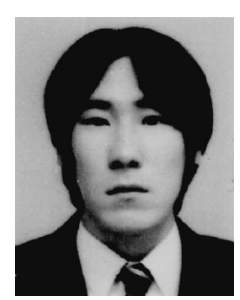

(学生員) 1985 年 2 月 10 日生。 2007 年東京電 機大学工学部電気工学科卒業。同年 4 月東京電 機大学大学院工学研究科電気工学専攻博士前期過 程入学。高温超電導限流器の開発に関する研究に 従事。

高 橋 陽 介（非会員） 1984 年 7 月 17 日生。 2004 年東京電

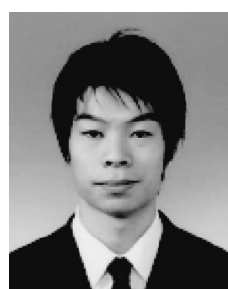
機大学工学部電気工学科入学。現在, 高温超電導 限流器の開発に関する研究に従事。

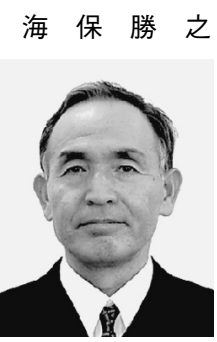

（正員） 1942 年 12 月 4 日生。1966 年東京工業 大学電気工学科卒業。同年 4 月通産省電気試験所 （現（独）産業技術総合研究所）入所。2003 年定 年退官。現在同所テクニカルスタッフ及び東京電 機大学非常勤講師。主として抵抗型超電導限流器 の実用化開発に従事。工学博士。IEEE, 低温工学 協会会員。

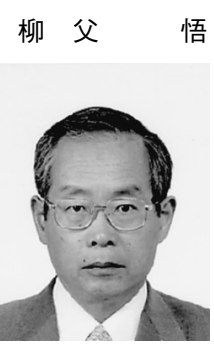

デミー会員。
悟（正員） 1941 年 7 月 15 日生。1964 年 3 月東京 大学工学部電気工学科卒業。同年 4 月 (株) 東 芝入社。現在, 東京電機大学教授。Visiting Prof, Liverpool。西安交通大学名誉教授。1972 年英国リ バプール大学 Ph.D., 工学博士。主として高電圧大 電流現象の研究および同機器開発に従事。IEEE, IEE フェロー, C.Eng., Current Zero Club, 英国 Royal Academy of Engineer FREng, 日本工学アカ 